\title{
Meta-analysis of the relationship between single nucleotide polymorphism of IL-10-1082G/A and rheumatic heart disease
}

\author{
Weiran Dai', Ziliang Ye ${ }^{1,2}$, Haili Lu ${ }^{2}$, Qiang Su ${ }^{1}$, Hui Li ${ }^{3}$ and Lang Li ${ }^{1}$ \\ ${ }^{1}$ Department of Cardiology, the First Affiliated Hospital of Guangxi Medical University, Guangxi Cardiovascular Institute, Nanning, \\ Guangxi, China \\ ${ }^{2}$ Guangxi Medical University, Nanning, Guangxi, China \\ ${ }^{3}$ Department of Infectious Diseases, the First Affiliated Hospital of Guangxi Medical University, Nanning, Guangxi, China
}

Correspondence to: Lang Li, email: drrlilang@126.com

Keywords: IL-10-1082G/A; single nucleotide polymorphism; rheumatic heart disease; correlation; meta-analysis

Received: July 10, $2017 \quad$ Accepted: November 09, $2017 \quad$ Published: January 03, 2018

Copyright: Dai et al. This is an open-access article distributed under the terms of the Creative Commons Attribution License 3.0 (CC BY 3.0), which permits unrestricted use, distribution, and reproduction in any medium, provided the original author and source are credited.

\section{ABSTRACT}

Background: The results showed that there was a certain correlation between the single nucleotide polymorphism of IL-10-1082G/A and rheumatic heart disease, but there was no systematic study to verify this conclusion.

Aims: Systematic review of the association between single nucleotide polymorphism of IL-10-1082G/A locus and rheumatic heart disease.

Materials and Methods: Computer retrieval PubMed, EMbase, Cochrane Library, CBM, CNKI, VIP and Data WanFang, the retrieval time limit from inception to June 2017. A case control study of single nucleotide polymorphisms and rheumatic heart disease in patients with rheumatic heart disease in the IL-10-1082G / A was collected. Two researchers independently screened the literature, extracted data and evaluated the risk of bias in the study, and using RevMan5.3 software for data analysis.

Results: A total of 3 case control studies were included, including 318 patients with rheumatic heart disease and 502 controls. Meta-analysis showed that there was no correlation between IL-10-1082G/A gene polymorphism and rheumatic heart disease [AA+AG VS GG: $O R=0.62,95 \% \mathrm{CI}(0.28,1.39), P=0.25$; AA VS AG+GG: $O R=0.73,95 \%$ CI (0.54, 1.00), $P=0.05$; AA VS GG: OR $=0.70,95 \% \mathrm{CI}(0.47,1.05), P=0.08$; AG VS GG: OR $=0.65,95 \%$ CI $(0.22,1.92), P=0.43$; A VS G: OR $=0.87,95 \%$ CI $(0.71,1.06), P=$ 0.17].

Conclusions: When AA is a recessive gene, the single nucleotide polymorphism of IL-10-1082G/A is associated with the presence of rheumatic heart disease. Due to the limitations of the quantity and quality of the included literatures, the further research results were still needed.

\section{INTRODUCTION}

Rheumatic heart disease (RHD) is a class of autoimmune diseases caused by beta hemolytic group A induced by Streptococcus [1-6]. The results of the study show that the streptococcus antigens can simulate the human protein (especially in the heart of the protein) molecules, which lead to RHD patients have their own immune response [7-9]. Cardiac involvement can cause inflammation of the heart, the heart and the heart, resulting in permanent damage to the heart valve and eventually death due to heart failure $[10,11]$. Despite the continuous improvement of the modern medical environment, the RHD is still one of the important diseases causing human deaths in underdeveloped areas. According to incomplete statistics, the number of RHD patients around the world is approximately 16000000 [12], and the annual number of new cases and deaths are growing, RHD to become one of the world's public health problems.

Domestic and foreign research results show that: RHD is a disease caused by genetic [13,14], environmental $[15,16]$ and autoimmune factors $[17,18]$, but the specific mechanism is unclear. Many scholars have carried out some research on RHD at the gene level, among them, the single nucleotide polymorphism of IL-10-1082G/A site is one of the key content of the research. Settin et al. pointed out that: there is a certain correlation between the 
IL-10-1082G/A site single nucleotide polymorphism and the incidence of RHD [19] [20-22]. But H Chou [23], a Chinese scholar, found that there was no correlation between the IL-10-1082G/A gene polymorphism and the incidence of RHD in the Han population of Taiwan. Because there is a big gap between the results of a single study, and lacking of effective theoretical guidance.

This study used systematic evaluation method to analyze the correlation between IL-10-1082G/A and RHD, and provide some reference for the pathogenesis and genetic susceptibility of RHD from the perspective of evidence-based medicine.

\section{MATERIALS AND METHODS}

\section{Data and methods}

\section{Inclusion and exclusion criteria}

Inclusion criteria: (1) The correlation between IL-10-1082G/A site single nucleotide polymorphism and rheumatic heart disease; (2) Study type: case control study; (3) Each study should provide a direct or indirect ratio (OR) value of the two groups of genotype frequencies; (4) Patients with rheumatic heart disease, including mitral valve disease, aortic valve disease and combined valvular disease, patient's age, sex, combined disease, family history is not limited; In the control group, most of the patients were healthy, and the residents were randomly selected; There was no blood relationship between the subjects in each group; (5) The genotype distribution of the control group was consistent with the Hardy-Weinberg (H-W) genetic equilibrium; (6) Research object is human.

\section{Exclusion criteria}

(1) Perspective study; (2) Repeated reports; (3) Abstracts, reviews, and information is not all in the form of abstracts; (4) Zoopery; (5) Information is incomplete or unable to extract the data from the literature.

\section{Retrieval strategy}

All the subjects were used to retrieve the database. English search terms was rheumatic heart disease, disease, rheumatic heart or diseases, IL-10-1082, mutation, polymorphism, variant, as shown in Table 1. Chinese search term for rheumatic heart disease, gene polymorphism, IL-10-1082. The retrieval time limit from inception to June 2017.

\section{Literature screening, data extraction and risk assessment of bias}

Two researchers independently screened the literature, extracted data and evaluated the risk of bias in the study.
In case of disagreement, discuss the solution or hand in the decision by the third party. Extracting data from the data of self-made data. The main contents including: (1) Included in the study of the basic information, including research topics, the first author, published a magazine and time, etc; (2) Key elements of risk assessment of bias; (3) Distribution frequency of genotype in case group and control group; The bias risk was evaluated by NOS scale (Scale NewcastleOttawa).

\section{Statistical analysis}

Meta-analysis was carried out using RevMan 5.3 software. First of all, the control group was included in the study of the genetic model for the weinberg hardy balance (HWE) test, if $P<0.05$, then the control group genotype does not meet HWE. Then 5 genetic models were calculated, respectively, including dominant model $(\mathrm{AA}+\mathrm{AG}$ vs $\mathrm{GG})$, implicit model (AA vs $\mathrm{AG}+\mathrm{GG}$ ), codominant model (AA vs GG), codominant model (AG vs GG) and Allele model (A vs G). The OR value and its $95 \%$ CI were used to analyze the effect of combined analysis, and the test level of $=0.05$ was analyzed by Meta. The heterogeneity between the results was using the chi square test for analysis (test set the standard for alpha $=0.1$ ), and combined with $\mathrm{I}^{2}$ quantitatively determine the size heterogeneity. If the research results were not statistically different, the fixed effect model was used for Meta-analysis. If the research results were statistically different, the random effects model was used to analyze the effects of Meta on the exclusion of significant clinical heterogeneity. Obvious clinical heterogeneity was treated by subgroup analysis, such as the different subgroups of ethnic groups, or sensitivity analysis, and other methods of treatment, or descriptive analysis [24-27].

\section{RESULTS}

\section{Literature search results}

A total of 96 articles were retrieved, after layer by layer screening, the final 3 case control studies were included [28-30], including three English literatures and 0 Chinese literatures. A total of 318 patients with rheumatic heart disease and 502 control subjects, literature screening process and results are shown in Figure 1.

\section{The basic characteristics of the included studies and the results of the risk assessment of bias}

One article come from Saudi Arabia, the average age of the case group was $(19.2+5.2)$ years old, the average age of the control group was $(20.6+4.5)$ years old, PCR method was used to detect IL-10-1082G/A, the genes of the control group were accord with Hardy-Weinberg equilibrium, Newcastle-Ottawa Scale score of 9 points; 


\section{Table 1: PubMed retrieval strategy}

\#1 Rheumatic Heart Disease or Disease, Rheumatic Heart or Diseases, Rheumatic Heart or Heart Disease, Rheumatic or Bouillaud Disease or Disease, Bouillaud

\begin{tabular}{ll}
\hline$\# 2$ & IL 10-1082 \\
$\# 3$ & mutation \\
$\# 4$ & polymorphism \\
$\# 5$ & variant \\
$\# 6$ & $\# 1$ AND \#2 AND (\#3 OR \#4 OR \#5) \\
\hline
\end{tabular}

one article come from Egypt, The age of the study population ranged from 5 18 years old, PCR method was used to detect IL-10-1082G/A, the genes of the control group were accord with Hardy-Weinberg equilibrium, Newcastle-Ottawa Scale score of 8 points; one article come from Pakistan, the average age of the case group was $(30 \pm 14.5)$ years old, the average age of the control group was $(45 \pm 12.7)$ years old, PCR method was used to detect IL-10-1082G/A, the genes of the control group were accord with Hardy-Weinberg equilibrium, NewcastleOttawa Scale score of 9 points. As shown in Table 2.

\section{Results of Meta-analysis}

Dominant model (AA+AG vs GG). A total of 318 cases and 502 controls were included. With the genotype $\mathrm{AA}+\mathrm{AG}$ as the exposure factor, the genotype GG was the nonexposure factor. Fixed effect model meta-analysis showed that $\mathrm{I}^{2}=76 \%, P=0.02$, there was a large heterogeneity, so we use a random effects model. Random effects model metaanalysis showed that there was no association between the polymorphism of the gene and RHD [OR $=0.62,95 \% \mathrm{CI}$ $(0.28,1.39), P=0.25]$. As shown in Figure 2 .
Obtain relevant literature through database retrieval,a total of 96 articles was retrieval, of which 58 articles in Pubmed,32 articles in EMbase,none article in the cochrance library. 3 articles in CMB, 2 articles in CNKI, 1 article in Wang Fang Data

\section{Through other} resources to supplement the relevant literature $(n=0)$

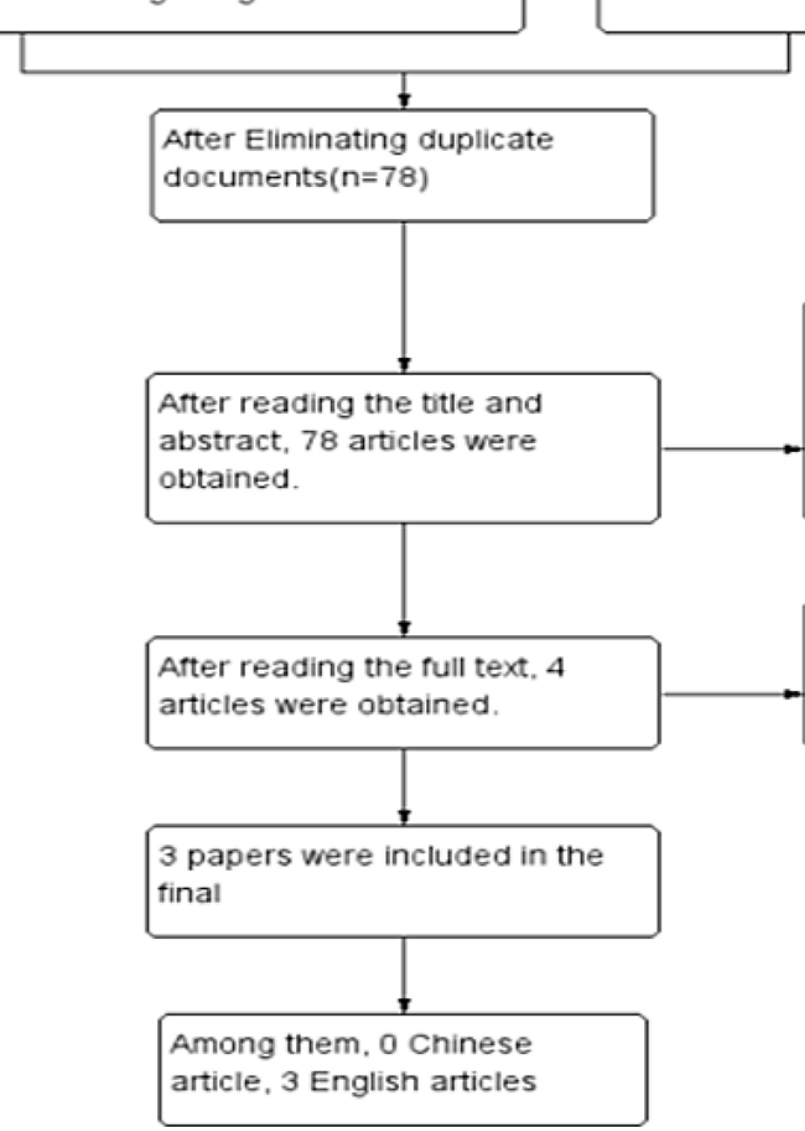

A total of 74 articles were excluded, of which 2 were only abstracts, 2 articles were reviewed and 68 were not related.

Exclude one articles not in accordance with the principles of HWE

Figure 1: Process and results of literature selection. 
Table 2: The basic characteristics of the included studies and the results of the risk assessment of bias

\begin{tabular}{|c|c|c|c|c|c|c|c|c|c|c|c|}
\hline \multirow[b]{2}{*}{$\begin{array}{l}\text { Inclusion } \\
\text { study }\end{array}$} & \multirow[b]{2}{*}{ Country } & \multirow[b]{2}{*}{ Age } & \multirow{2}{*}{$\begin{array}{c}\text { Gene } \\
\text { detection } \\
\text { method }\end{array}$} & \multicolumn{2}{|c|}{ sample size } & \multicolumn{2}{|c|}{ Case group } & \multicolumn{2}{|c|}{ Control group } & \multirow[b]{2}{*}{ HWE } & \multirow[b]{2}{*}{ NOS } \\
\hline & & & & $\begin{array}{l}\text { Case } \\
\text { group }\end{array}$ & $\begin{array}{l}\text { control } \\
\text { group }\end{array}$ & $\mathbf{G A}+\mathbf{A A}$ & GG & $\mathbf{G A}+\mathbf{A A}$ & GG & & \\
\hline $\begin{array}{l}\text { Abdallah A } \\
\quad 2016\end{array}$ & $\begin{array}{c}\text { Saudi } \\
\text { Arabia }\end{array}$ & $\begin{array}{c}\text { case group }(19.2+5.2) \text { years old, control group } \\
(20.6+4.5) \text { years old }\end{array}$ & PCR & 118 & 200 & 99 & 19 & 169 & 31 & coincidence & 9 \\
\hline Settin A 2007 & Egypt & $5 \sim 18$ years old & PCR & 50 & 98 & 38 & 12 & 93 & 5 & coincidence & 8 \\
\hline $\begin{array}{l}\text { Rehman S } \\
2013\end{array}$ & Pakistan & $\begin{array}{c}\text { case group }(30+14.5) \text { years old, control group }(45 \\
+12.7) \text { years old }\end{array}$ & PCR & 150 & 204 & 101 & 49 & 140 & 64 & coincidence & 9 \\
\hline
\end{tabular}

Implicit model (AA vs AG+GG). A total of 318 cases and 502 controls were included. With the genotype $\mathrm{AA}$ as the exposure factor, the genotype $\mathrm{AG}+\mathrm{GG}$ was the non-exposure factor. Fixed effect model metaanalysis showed that $\mathrm{I}^{2}=84 \%, P=0.002$. There is a large heterogeneity, so we use a random effects model. Random effects model meta-analysis showed that there was no association between the polymorphism of the gene and $\mathrm{RHD}[\mathrm{OR}=0.73,95 \% \mathrm{CI}(0.54,1.00), P=0.05]$. As shown in Figure 3.

Codominant model (AA vs GG). A total of 168 cancer patients and 268 controls were included. With the genotype $\mathrm{AA}$ as the exposure factor, the genotype GG was the non-exposure factor. Fixed effect model meta-analysis showed that $\mathrm{I}^{2}=0 \%, P=0.81$, the heterogeneity was small, so we use a fixed effect model. Fixed effect model meta-analysis results showed that there was no association between the polymorphism of the gene and RHD [OR = $0.70,95 \% \mathrm{CI}(0.47,1.05), P=0.08]$. As shown in Figure 4 .
Codominant model (AG vs GG). A total of 230 cancer patients and 334 controls were included. With the genotype $A G$ as the exposure factor, the genotype GG was the non-exposure factor. Fixed effect model metaanalysis showed that $\mathrm{I}^{2}=85 \%, P=0.001$, there is a large heterogeneity, so we use a random effects model. Random effects model meta-analysis showed that there was no association between the polymorphism of the gene and RHD [OR $=0.65,95 \%$ CI $(0.22,1.92), P=0.43]$. As shown in Figure 5.

Allele model (A vs G). A total of 308 patients and 502 controls were included. The allele $\mathrm{G}$ was the exposure factor, and the allele A was non-exposure factor. Fixed effect model meta-analysis showed that $\mathrm{I}^{2}=0 \%, P=0.93$, the heterogeneity was small, so we use a fixed effect model. Fixed effect model meta-analysis results showed that there was no association between the polymorphism of the gene and RHD [OR $=0.87,95 \%$ CI $(0.71,1.06)$, $P=0.17]$. As shown in Figure 6 .

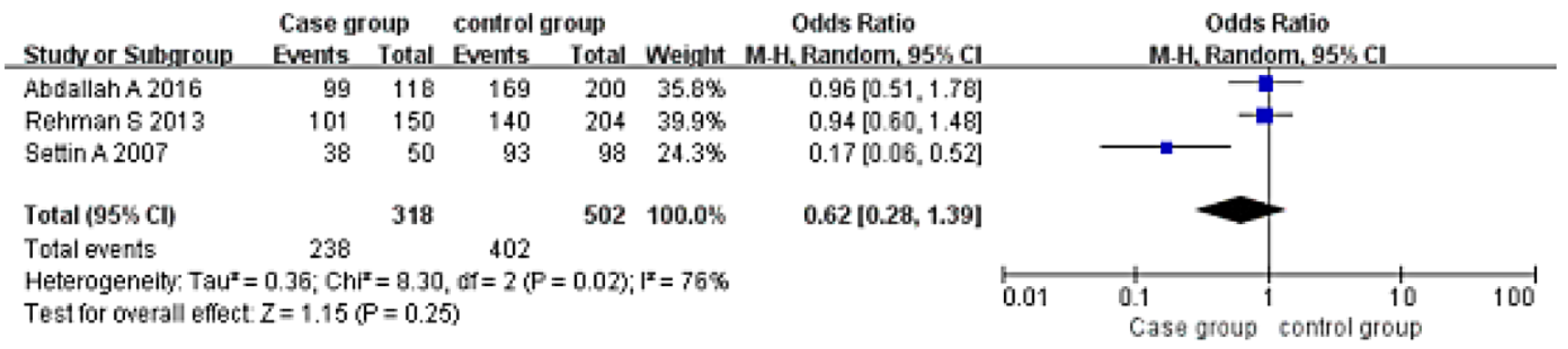

Figure 2: Meta-analysis of the correlation between the single nucleotide polymorphism of the IL-10-1082G/A site and rheumatic heart disease (AA+AG vs GG).

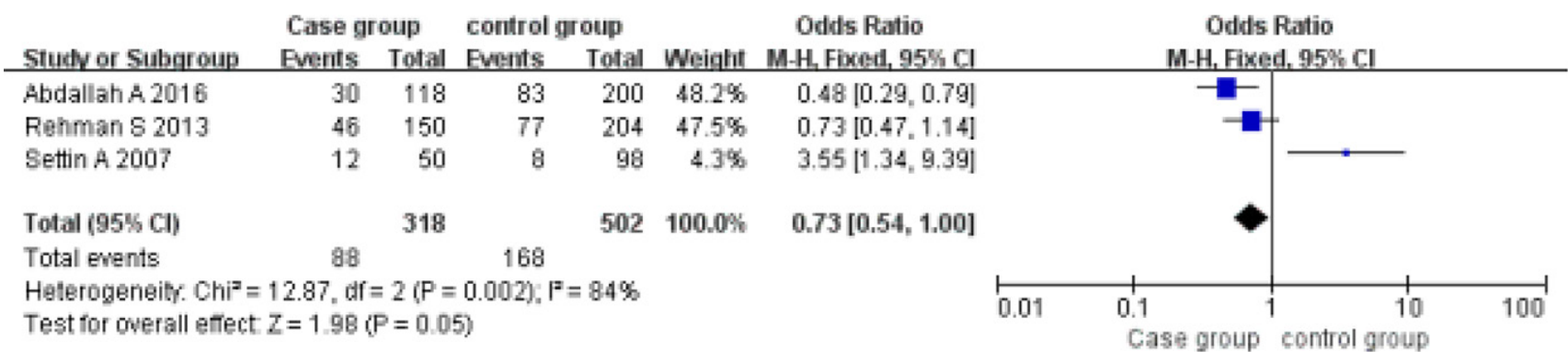

Figure 3: Meta-analysis of the correlation between the single nucleotide polymorphism of the IL-10-1082G/A site and rheumatic heart disease (AA vs AG+GG). 


\section{DISCUSSION}

Interleukin 10 (IL-10) is a newly discovered cytokine in recent years, also known as cytokine synthesis inhibitory factor, with 178 amino acid residues in a single chain glycoprotein ( $\mathrm{N}$ terminal 18 amino acid signal peptide sequence) [31-35]. IL-10 molecular weight $35-40 \mathrm{kDa}$, usually as a two polymer, its gene is single copy gene. Human IL-10 gene is located on chromosome 1 , limiting endonuclease map indicated that the gene contains at least three interval sequences, with other known cytokines gene nucleotide sequence of goods corresponding protein sequence comparison of IL-10 and these cytokines no obvious sequence homology. IL-10 is mainly produced by Th2 cells, but Tho cells, Th cells, $\mathrm{CD} 8+\mathrm{T}$ cells, activated B cells, monocytes-macrophages, Kupffer cells, liver cells, keratinocytes can also produce.
Interleukin-10 (IL-10) is an important inflammatory factor in the body [36-39]. It has the function of antivascular growth and immune suppression. It also has the dual regulation effect of inhibiting tumor growth and promoting tumor growth. In recent years, more and more researches about the relationship between IL-10 polymorphism and disease have been studied. Among them, the correlation between IL-10-1082G/A polymorphism and rheumatic heart disease is one of the most important parts of the study [40-42]. Related research $[43,44]$ pointed out that the increase of IL-10 expression in the serum of patients with rheumatic heart disease is closely related to the occurrence and progression of the disease, and with the increase of the level of IL10 expression, the worse the prognosis, the higher the mortality rate. Abdallah [30] study showed that the effect of IL-10 on the role of $1082 \mathrm{G} / \mathrm{A}$ in patients with

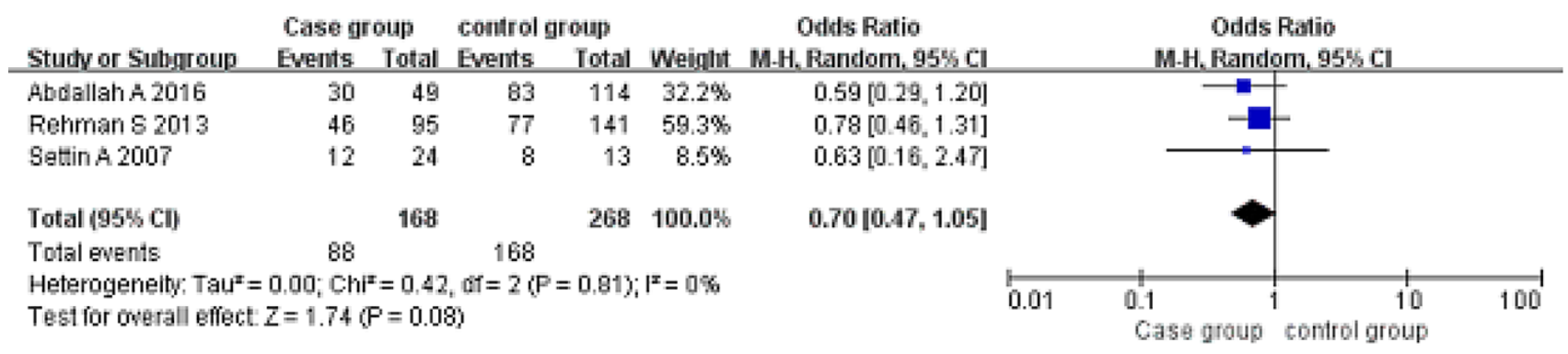

Figure 4: Meta-analysis of the correlation between the single nucleotide polymorphism of the IL-10-1082G/A site and rheumatic heart disease (AA vs GG).

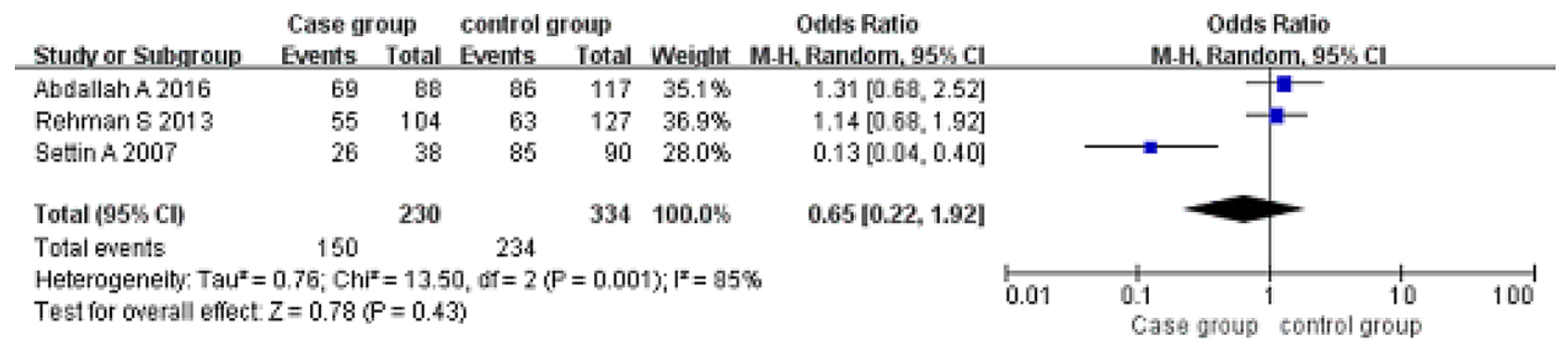

Figure 5: Meta-analysis of the correlation between the single nucleotide polymorphism of the IL-10-1082G/A site and rheumatic heart disease (AG vs GG).

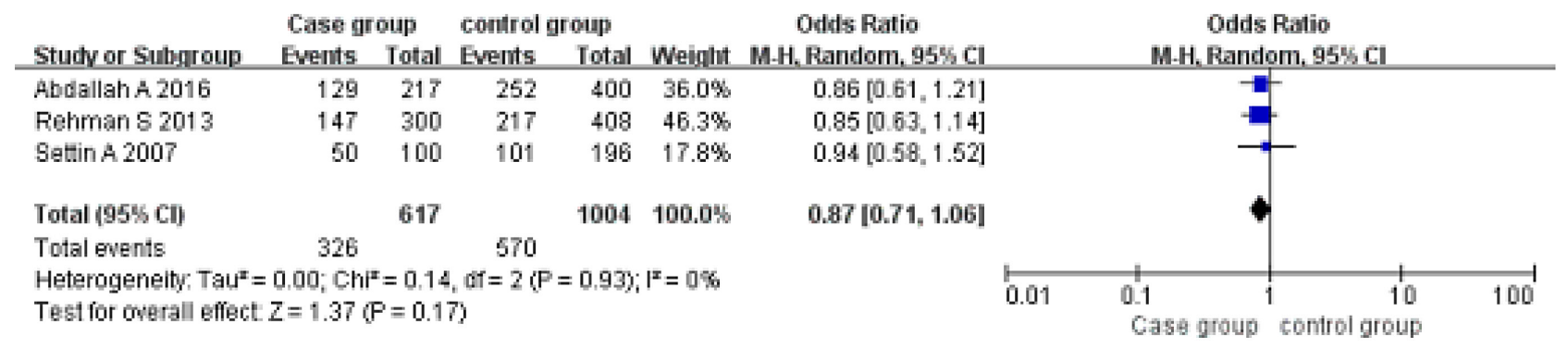

Figure 6: Meta-analysis of the correlation between the single nucleotide polymorphism of the IL-10-1082G/A site and rheumatic heart disease (A vs G). 
rheumatic heart disease is related to the single nucleotide polymorphisms (SNPs) in the gene promoter region. GG+GA gene polymorphism significantly increases the incidence of rheumatic heart disease in the population, AA gene polymorphism significantly reduces the incidence of rheumatic heart disease in the population, but the conclusion is still not uniform. Therefore, this study collect related case - control study and carries on the meta-analysis, further clarify the association between IL10-1082G/A polymorphism and rheumatic heart disease, in order to provide a theoretical basis for the clear natural immunity and the pathogenesis of rheumatic heart disease.

The study included 3 case-control studies, a total of 318 patients with rheumatic heart disease and 502 control subjects. Our results showed that the IL-10-1082G/A polymorphism in the Implicit model (AA vs $\mathrm{AG}+\mathrm{GG}$ ) has a certain correlation with the risk of rheumatic heart disease, but dominant model (AA+AG vs GG), codominant model (AA vs GG), codominant model (AG vs GG) and Allele model (A vs G) have no associated with the risk of rheumatic heart disease. In this study, we found that there is a certain heterogeneity among the studies, which may including: (1) The cases and controls involved in the study were derived from different regions, ethnic, and the Inclusion criteria among case group and control group are not agreement; (2) The article Included in the study were published in the literature, not included the gray literature; (3) Different types of disease diagnosis methods from different countries or regions are different, which may bring about a certain heterogeneity.

The limitations of this study including: (1) the incidence of rheumatic heart disease is related to many factors. But in this study, the correlation between one gene polymorphism and rheumatic heart disease was studied, and the interaction of gene and gene environment was analyzed, and the interaction of gene and gene environment was analyzed. (2) Because of the small number of the included studies, the study was not further divided into subgroups according to the type of disease and race. If there are more studies in the future, we will further study the correlation between different types of disease and race. (3) The Meta analysis was included in the study population for the African population, and did not incorporate studies from Europe, Asia, and North America. So the conclusions of this study may not be applicable to people in Europe, Asia and North America.

In conclusion, this study found that the polymorphism of IL-10-1082G/A gene may be related to the risk of rheumatic heart disease. Due to the quantity and quality of the research, the conclusions of this study need to be carried out to verify the quality of the large sample.

\section{ACKNOWLEDGMENTS}

This study was supported by the First Affiliated Hospital of Guangxi Medical University.

\section{CONFLICTS OF INTEREST}

The authors have no funding sources or conflicts of interest to disclose.

\section{REFERENCES}

1. Reményi B, Wilson N, Steer A, Ferreira B, Kado J, Kumar K, Lawrenson J, Maguire G, Marijon E, Mirabel M, Mocumbi AO, Mota C, Paar J, et al. World Heart Federation criteria for echocardiographic diagnosis of rheumatic heart disease - an evidence-based guideline. Nat Rev Cardiol. 2012; 9:297-309. https://doi.org/10.1038/nrcardio.2012.7.

2. Steer AC, Carapetis JR. Prevention and treatment of rheumatic heart disease in the developing world. Nat Rev Cardiol. 2009; 6:689-98. https://doi.org/10.1038/ nrcardio.2009.162.

3. Carapetis JR. The stark reality of rheumatic heart disease. Eur Heart J. 2015; 36:1070-73. https://doi.org/10.1093/ eurheartj/ehu507.

4. He VY, Condon JR, Ralph AP, Zhao Y, Roberts K, de Dassel JL, Currie BJ, Fittock M, Edwards KN, Carapetis JR. Long-Term Outcomes From Acute Rheumatic Fever and Rheumatic Heart Disease: A Data-Linkage and Survival Analysis Approach. Circulation. 2016; 134:222-32. https:// doi.org/10.1161/CIRCULATIONAHA.115.020966.

5. Kumar RK, Tandon R. Rheumatic fever \& rheumatic heart disease: the last 50 years. Indian J Med Res. 2013; 137:643-58.

6. Zühlke L, Mirabel M, Marijon E. Congenital heart disease and rheumatic heart disease in Africa: recent advances and current priorities. Heart. 2013; 99:1554-61. https://doi. org/10.1136/heartjnl-2013-303896.

7. Engelman D, Kado JH, Reményi B, Colquhoun SM, Carapetis JR, Wilson NJ, Donath S, Steer AC. Screening for rheumatic heart disease: quality and agreement of focused cardiac ultrasound by briefly trained health workers. BMC Cardiovasc Disord. 2016; 16:30. https://doi.org/10.1186/ s12872-016-0205-7.

8. Irlam J, Mayosi BM, Engel M, Gaziano TA. Primary prevention of acute rheumatic fever and rheumatic heart disease with penicillin in South African children with pharyngitis: a cost-effectiveness analysis. Circ Cardiovasc Qual Outcomes. 2013; 6:343-51. https://doi.org/10.1161/ CIRCOUTCOMES.111.000032.

9. Colquhoun SM, Carapetis JR, Kado JH, Reeves BM, Remenyi B, May W, Wilson NJ, Steer AC. Pilot study of nurse-led rheumatic heart disease echocardiography screening in Fiji-a novel approach in a resource-poor setting. Cardiol Young. 2013; 23:546-52. https://doi. org/10.1017/S1047951112001321.

10. Guilherme L, Kalil J. Rheumatic Heart Disease: Molecules Involved in Valve Tissue Inflammation Leading to the Autoimmune Process and Anti-S. pyogenes Vaccine. Front Immunol. 2013; 4:352. https://doi.org/10.3389/ fimmu.2013.00352. 
11. Irlam JH, Mayosi BM, Engel ME, Gaziano TA. A cost-effective strategy for primary prevention of acute rheumatic fever and rheumatic heart disease in children with pharyngitis. S Afr Med J. 2013; 103:894-5. https:// doi.org/10.7196/SAMJ.7244.

12. Rémond M, Atkinson D, White A, Brown A, Carapetis J, Remenyi B, Roberts K, Maguire G. Are minor echocardiographic changes associated with an increased risk of acute rheumatic fever or progression to rheumatic heart disease? Int J Cardiol. 2015; 198:117-22. https://doi. org/10.1016/j.ijcard.2015.07.005.

13. Guilherme L, Ramasawmy R, Kalil J. Rheumatic fever and rheumatic heart disease: genetics and pathogenesis. Scand J Immunol. 2007; 66:199-207. https://doi.org/10.1111/ j.1365-3083.2007.01974.x.

14. Kaushal A, Kumar D, Khare S, Kumar A. speB gene as a specific genetic marker for early detection of rheumatic heart disease in human. Cell Mol Biol (Noisy-le-grand). 2012; 58:50-4.

15. Roberts K, Colquhoun S, Steer A, Reményi B, Carapetis J. Screening for rheumatic heart disease: current approaches and controversies. Nat Rev Cardiol. 2013; 10:49-58. https:// doi.org/10.1038/nrcardio.2012.157.

16. Phillips DI, Osmond C. Is susceptibility to chronic rheumatic heart disease determined in early infancy? An analysis of mortality in Britain during the 20th century. Glob Cardiol Sci Pract. 2014; 2014:464-72. https://doi. org/10.5339/gcsp.2014.59.

17. Ntali S, Damjanov N, Drakakis P, Ionescu R, Kalinova D, Rashkov R, Malamitsi-Puchner A, Mantzaris G, Michala L, Pamfil C, Rednic S, Tektonidou MG, Tsiodras S, et al. Women's health and fertility, family planning and pregnancy in immune-mediated rheumatic diseases: a report from a south-eastern European Expert Meeting. Clin Exp Rheumatol. 2014; 32:959-68.

18. Guilherme L. Rheumatic Heart Disease: Key Points on Valve Lesions Development. J Clin Exp Cardiolog. 2012; 01. https://doi.org/10.4172/2155-9880.S3-006.

19. Gupta U, Mir SS, Garg N, Agarwal SK, Pande S, Mittal B. Association study of inflammatory genes with rheumatic heart disease in North Indian population: A multi-analytical approach. Immunol Lett. 2016; 174:53-62. https://doi. org/10.1016/j.imlet.2016.04.012.

20. Wang Y, Zheng J, Liu P, Yu X, Zhou D, Jiang L, You Y, Zhou Y. P015 Association between the Interleukin 10 $-1082 \mathrm{G}>\mathrm{A}$ Polymorphism and Coronary Heart Disease Risk in a Caucasian Population: A Meta-analysis. Int $\mathrm{J}$ Immunogenet. 2012; 147:S12-3.

21. Talaat RM, Alrefaey SA, Bassyouni IH, Ashour ME, Raouf AA. Genetic polymorphisms of interleukin 6 and interleukin 10 in Egyptian patients with systemic lupus eythematosus. Lupus. 2016; 25:255-64. https://doi. org/10.1177/0961203315615219.

22. Wang F, Quan QQ, Zhang CL, Li YB, Jiang TB. Association between polymorphisms in the interleukin-10 gene and risk of abdominal aortic aneurysm. Genet Mol Res. 2015; 14:17599-604. https://doi.org/10.4238/2015. December.21.32.

23. Chou HT, Tsai CH, Chen WC, Tsai FJ. Lack of association of genetic polymorphisms in the interleukin-1beta, interleukin-1 receptor antagonist, interleukin-4, and interleukin-10 genes with risk of rheumatic heart disease in Taiwan Chinese. J Heart Valve Dis. 2003; 12:38-44.

24. Egger M, Davey Smith G, Schneider M, Minder C. Bias in meta-analysis detected by a simple, graphical test. BMJ. 1997; 315:629-34. https://doi.org/10.1136/ bmj.315.7109.629.

25. Whiting PF, Wolff RF, Deshpande S, Di Nisio M, Duffy S, Hernandez AV, Keurentjes JC, Lang S, Misso K, Ryder S, Schmidlkofer S, Westwood M, Kleijnen J. Cannabinoids for Medical Use: A Systematic Review and Meta-analysis. JAMA. 2015; 313:2456-73. https://doi.org/10.1001/ jama.2015.6358.

26. Deeks JJ, Altman DG, Bradburn MJ. Statistical Methods for Examining Heterogeneity and Combining Results from Several Studies in Meta-Analysis. BMJ Publishing Group; 2008 .

27. Shachar M. Meta-Analysis: The Preferred Method of Choice for the Assessment of Distance Learning Quality Factors. Int Rev Res Open Distance Learn. 2008; 9:1-15. https://doi.org/10.19173/irrodl.v9i3.493.

28. Rehman S, Akhtar N, Saba N, Munir S, Ahmed W, Mohyuddin A, Khanum A. A study on the association of TNF- $\alpha(-308)$, IL-6(-174), IL-10(-1082) and IL-1Ra(VNTR) gene polymorphisms with rheumatic heart disease in Pakistani patients. Cytokine. 2013; 61:527-31. https://doi. org/10.1016/j.cyto.2012.10.020.

29. Settin A, Abdel-Hady H, El-Baz R, Saber I. Gene polymorphisms of TNF-alpha(-308), IL-10(-1082), IL6(-174), and IL-1Ra(VNTR) related to susceptibility and severity of rheumatic heart disease. Pediatr Cardiol. 2007; 28:363-71. https://doi.org/10.1007/s00246-006-0002-7.

30. Abdallah AM, Alnuzha A, Al-Mazroea AH, Eldardear AE, AlSamman AY, Almohammadi Y, Al-Harbi KM. IL10 Promoter Polymorphisms are Associated with Rheumatic Heart Disease in Saudi Arabian Patients. Pediatr Cardiol. 2016; 37:99-105. https://doi.org/10.1007/s00246-015-1245-y.

31. Zigmond E, Bernshtein B, Friedlander G, Walker CR, Yona S, Kim KW, Brenner O, Krauthgamer R, Varol C, Müller W, Jung S. Macrophage-restricted interleukin-10 receptor deficiency, but not IL-10 deficiency, causes severe spontaneous colitis. Immunity. 2014; 40:720-33. https://doi. org/10.1016/j.immuni.2014.03.012.

32. Kotlarz D, Beier R, Murugan D, Diestelhorst J, Jensen O, Boztug K, Pfeifer D, Kreipe H, Pfister ED, Baumann U, Puchalka J, Bohne J, Egritas O, et al. Loss of interleukin-10 signaling and infantile inflammatory bowel disease: implications for diagnosis and therapy. Gastroenterology. 2012; 143:347-55. https://doi.org/10.1053/j. gastro.2012.04.045. 
33. Matsumoto M, Baba A, Yokota T, Nishikawa H, Ohkawa Y, Kayama H, Kallies A, Nutt SL, Sakaguchi S, Takeda K, Kurosaki T, Baba Y. Interleukin-10-producing plasmablasts exert regulatory function in autoimmune inflammation. Immunity. 2014; 41:1040-51. https://doi.org/10.1016/j. immuni.2014.10.016.

34. Deng M, Ma T, Yan Z, Zettel KR, Scott MJ, Liao H, Frank A, Morelli AE, Sodhi CP, Hackam DJ, Billiar TR. Tolllike Receptor 4 Signaling on Dendritic Cells Suppresses Polymorphonuclear Leukocyte CXCR2 Expression and Trafficking via Interleukin 10 During Intra-abdominal Sepsis. J Infect Dis. 2016; 213:1280-88. https://doi. org/10.1093/infdis/jiv562.

35. Metghalchi S, Ponnuswamy P, Simon T, Haddad Y, Laurans L, Clément M, Dalloz M, Romain M, Esposito B, Koropoulis V, Lamas B, Paul JL, Cottin Y, et al. Indoleamine 2,3-Dioxygenase Fine-Tunes Immune Homeostasis in Atherosclerosis and Colitis through Repression of Interleukin-10 Production. Cell Metab. 2015; 22:460-71. https://doi.org/10.1016/j.cmet.2015.07.004.

36. Peterson RA. Regulatory T-cells: diverse phenotypes integral to immune homeostasis and suppression. Toxicol Pathol. 2012; 40:186-204. https://doi. org/10.1177/0192623311430693.

37. Hörber S, Hildebrand DG, Lieb WS, Lorscheid S, Hailfinger S, Schulze-Osthoff K, Essmann F. The Atypical Inhibitor of NF- $\kappa \mathrm{B}, \mathrm{I} \kappa \mathrm{B} \zeta$, Controls Macrophage Interleukin-10 Expression. J Biol Chem. 2016; 291:12851-61.

38. Liu WH, Liu JJ, Wu J, Zhang LL, Liu F, Yin L, Zhang MM, $\mathrm{Yu}$ B. Novel mechanism of inhibition of dendritic cells maturation by mesenchymal stem cells via interleukin-10 and the JAK1/STAT3 signaling pathway. PLoS One. 2013; 8:e55487. https://doi.org/10.1371/journal.pone.0055487.

39. Kishore R, Krishnamurthy P, Garikipati VN, Benedict C, Nickoloff E, Khan M, Johnson J, Gumpert AM, Koch WJ,
Verma SK. Interleukin-10 inhibits chronic angiotensin IIinduced pathological autophagy. J Mol Cell Cardiol. 2015; 89:203-13. https://doi.org/10.1016/j.yjmcc.2015.11.004.

40. Ates O, Musellim B, Ongen G, Topal-Sarikaya A. Interleukin-10 and tumor necrosis factor- $\alpha$ gene polymorphisms in tuberculosis. J Clin Immunol. 2008; 28:232-36. https://doi.org/10.1007/s10875-007-9155-2.

41. Costa GC, da Costa Rocha MO, Moreira PR, Menezes CA, Silva MR, Gollob KJ, Dutra WO. Functional IL-10 gene polymorphism is associated with Chagas disease cardiomyopathy. J Infect Dis. 2009; 199:451-54. https:// doi.org/10.1086/596061.

42. Lio D, Scola L, Crivello A, Colonna-Romano G, Candore G, Bonafé M, Cavallone L, Marchegiani F, Olivieri F, Franceschi C, Caruso C. Inflammation, genetics, and longevity: further studies on the protective effects in men of IL-10 -1082 promoter SNP and its interaction with TNF- $\alpha$ -308 promoter SNP. J Med Genet. 2003; 40:296-99. https:// doi.org/10.1136/jmg.40.4.296.

43. Lio D, Candore G, Crivello A, Scola L, Colonna-Romano G, Cavallone L, Hoffmann E, Caruso M, Licastro F, Caldarera CM, Branzi A, Franceschi C, Caruso C. Opposite effects of interleukin 10 common gene polymorphisms in cardiovascular diseases and in successful ageing: genetic background of male centenarians is protective against coronary heart disease. J Med Genet. 2004; 41:790-94. https://doi.org/10.1136/jmg.2004.019885.

44. Gambhir D, Lawrence A, Aggarwal A, Misra R, Mandal SK, Naik S. Association of tumor necrosis factor alpha and IL-10 promoter polymorphisms with rheumatoid arthritis in North Indian population. Rheumatol Int. 2010; 30:1211-17. https://doi.org/10.1007/s00296-009-1131-0. 